\title{
Correction to: Niche differentiation among invasive Ponto- Caspian Chelicorophium species (Crustacea, Amphipoda, Corophiidae) by food particle size
}

\author{
Péter Borza $(i)$ Thomas Huber - Patrick Leitner - Nadine Remund • \\ Wolfram Graf
}

Published online: 14 August 2018

(C) Springer Nature B.V. 2018

\section{Correction to: Aquat Ecol https://doi.org/10.1007/s10452-018-9653-8}

A calibration mistake caused systematic error in the microscopic measurements; all filter mesh size values should be divided by a factor of 2.56. As our conclusions were based on the inter- and intraspecific variations of the trait, this systematic error does not influence them in any way.

Filter mesh sizes ranged between 2.47 and $7.17 \mu \mathrm{m}$ in $C$. curvispinum, between 1.83 and $5.09 \mu \mathrm{m}$ in $C$. robustum, and between 1.03 and $2.68 \mu \mathrm{m}$ in $C$. sowinskyi. Interspecific differences were estimated

The original article can be found online at https://doi.org/10. 1007/s10452-018-9653-8.

P. Borza $(\square)$

GINOP Sustainable Ecosystems Group, MTA Centre for

Ecological Research, Klebelsberg Kuno utca 3,

Tihany 8237, Hungary

e-mail: borza.peter@okologia.mta.hu

P. Borza

Danube Research Institute, MTA Centre for Ecological

Research, Karolina út 29-31, Budapest 1113, Hungary

T. Huber · P. Leitner - W. Graf

Department of Water, Atmosphere and Environment, Institute for Hydrobiology and Water Management, BOKU - University of Natural Resources and Applied Life Sciences, Gregor Mendel Strasse 33, 1180 Vienna, Austria correctly as $1.12 \mu \mathrm{m}(S E=0.15)$ between $C$. curvispinum and $C$. robustum, and $1.37 \mu \mathrm{m}(S E=0.15)$ between $C$. robustum and $C$. sowinskyi. The correct version of Figure 2 and Table 3 are provided in this correction.

The 100-fold magnification mentioned in the text refers to the magnification of the microscope objective.

N. Remund

Info fauna - CSCF, Passage Maximilien-de-Meuron 6, 2000 Neuchâtel, Switzerland 
Fig. 2 Filter mesh sizes of Chelicorophium species as a function of body length. Lines represent the fitted values of the single-species linear mixed-effects models. This figure represents a rescaled version (all values divided by a factor of 2.56) of Fig. 2 in the original publication.

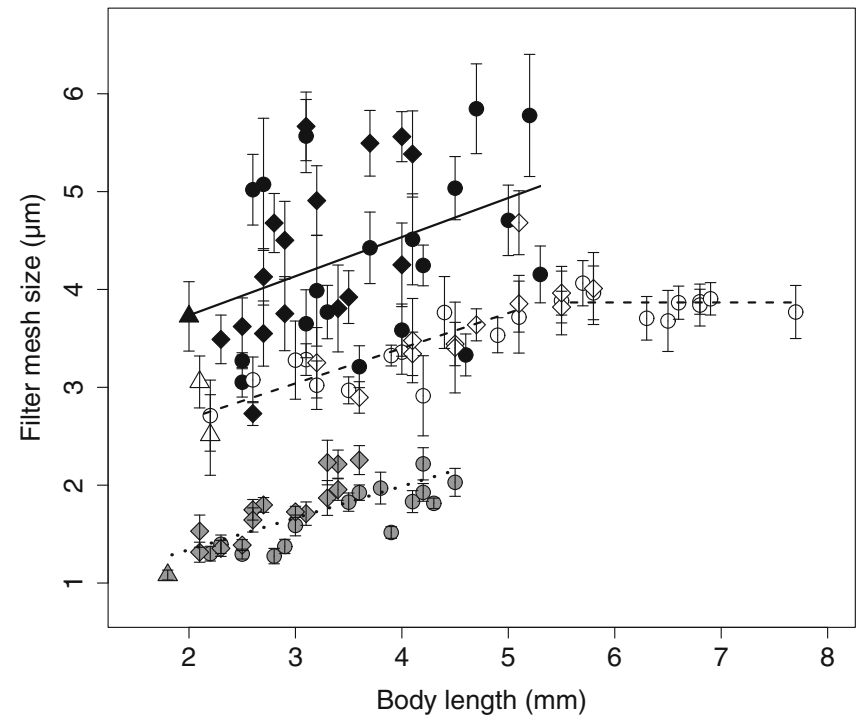

Legend

- C. curvispinum female

C. curvispinum male

$\Delta$ C. curvispinum juv.

C. robustum female

$\diamond$ C. robustum male

$\triangle$ C. robustum juv.

C. sowinskyi female

$\diamond$ C. sowinskyi male

$\triangle C$. sowinskyi juv.

C. curvispinum

- - C. robustum

.... C. sowinskyi

Table 3 Parameters and variance components of the single-species linear mixed-effects models. Note: the $P$-values of the parameter estimations and the variance components of the models are not affected by the calibration error

\begin{tabular}{|c|c|c|c|c|c|}
\hline Species & Intercept $(\mu \mathrm{m})$ & $\begin{array}{l}\text { Slope (body } \\
\text { length) }\end{array}$ & $\begin{array}{l}\text { Body length- } \\
\text { dependency (= fixed } \\
\text { effects) }\end{array}$ & $\begin{array}{l}\text { Among-individual } \\
\text { variation (= random } \\
\text { effects) }\end{array}$ & $\begin{array}{l}\text { Within-individual } \\
\text { variation (= residual) }\end{array}$ \\
\hline $\begin{array}{l}\text { C. } \\
\text { curvispinum }\end{array}$ & $\begin{array}{l}2.94 \\
\quad(S E=0.56 \\
\quad P<0.001)\end{array}$ & $\begin{array}{l}0.40 \\
\quad(S E=0.16 \\
P=0.015)\end{array}$ & 0.15 & 0.80 & 0.05 \\
\hline $\begin{array}{l}\text { C. robustum } \\
(<5.5 \mathrm{~mm})\end{array}$ & $\begin{array}{l}1.96 \\
\quad(S E=0.25 \\
P<0.001)\end{array}$ & $\begin{array}{l}0.36 \\
\quad(S E=0.06 \\
\quad P<0.001)\end{array}$ & 0.41 & 0.27 & 0.32 \\
\hline $\begin{array}{l}\text { C. robustum } \\
(\geq 5.5 \mathrm{~mm})\end{array}$ & $\begin{array}{l}3.87 \\
\quad(S E=0.03 \\
P<0.001)\end{array}$ & Not significant & - & 0.11 & 0.89 \\
\hline C. sowinskyi & $\begin{array}{l}0.69 \\
\quad(S E=0.18 \\
P<0.001)\end{array}$ & $\begin{array}{l}0.32 \\
\quad(S E=0.06 \\
\quad P<0.001)\end{array}$ & 0.52 & 0.44 & 0.04 \\
\hline
\end{tabular}

